\title{
Knowledge management for the sustainable development of the semi-arid region in Northeastern Brazil
}

\section{Lydia Maria Pinto Brito ${ }^{1}$ Naeldson Expedito Alves da Silva ${ }^{2}$ Ahiram Brunni Cartaxo de Castro ${ }^{3 *}$ (iD Cristine Hermann Nodari ${ }^{1}$ (i) Arthur William Pereira da Silva ${ }^{1}$ (I)}

${ }^{1}$ Universidade Potiguar (UnP), Natal, RN, Brasil.

${ }^{2}$ Universidade Federal Rural do Semi-Árido (UFERSA), Mossoró, RN, Brasil.

${ }^{3}$ Instituto Federal de Educação, Ciência e Tecnologia do Rio Grande do Norte (IFRN), 59015-000, Natal, RN, Brasil. E-mail: brunnicastro@hotmail.com. ${ }^{*}$ Corresponding author.

ABSTRACT: The objective of this study was to analyze the knowledge management perception in managers of a public university in the Brazilian Northeastern Semiarid Region, especially their tactical and strategic processes to produce knowledge about this region. The analysis was conducted according to the perspective of administrators at this university with a view to the sustainable development of the region. This was a qualitative descriptive study. All data were collected through structured interviews, using a questionnaire based on the Knowledge Management Diagnosis as a structuring model. Results showed that Knowledge Management is still a maturing practice. However, knowledge management is making institutional changes feasible and generating organization capacity to implement solutions and promote the sustainable development of the semi-arid region in the Northeastern Brazil.

Key words: diagnosis, knowledge management, public administration, university, semi-arid region, northeastern Brazil, sustainable development.

Gerenciamento do conhecimento para o desenvolvimento sustentável da região semiárida no Nordeste do Brasil

RESUMO: O objetivo deste estudo foi analisar a percepção da gestão do conhecimento em gestores de uma universidade pública na Região Semiárida do Nordeste brasileiro, especialmente seus processos táticos e estratégicos para produzir conhecimento sobre esta Região. A análise foi conduzida segundo a perspectiva de administradores nesta universidade tendo em vista o desenvolvimento sustentável da região. Este foi um estudo qualitativo. Todos os dados foram coletados por meio de entrevistas estruturadas, usando um questionário baseado no Diagnóstico de Gestão do Conhecimento como modelo estruturante. Os resultados mostraram que a Gestão do Conhecimento é uma prática que está amadurecendo. Entretanto, a gestão do conhecimento está viabilizando mudanças institucionais e gerando capacidade da organização para implementar soluções e promover o desenvolvimento sustentável da região semiárida no Nordeste do Brasil.

Palavras-chave: diagnóstico, gestão do conhecimento, administração pública, universidade, região semiárida, nordeste do Brasil, desenvolvimento sustentável.

\section{INTRODUCTION}

Knowledge Management (KM) deals with the way knowledge is coordinated, used, structured, and retrieved to generate value and benefits for institutions and the society (DONATE \& PABLO, 2015; ANDREEVA \& KIANTO, 2012). The KM also deals with infrastructure (Information and Communication Technologies, ICTs), cultural and transcultural factors, local skills, and management know-how and skills (ALEGRE et al., 2013) that support and improve institutional performance. Therefore, $\mathrm{KM}$ is the set of practices and initiatives for managers to create, transfer, and apply knowledge in organizations.
However, it is still difficult to understand how knowledge can modify a reality because knowledge takes different forms and various challenges are associated with its management, including as follows: the need for organizations to train specialists to filter the information that is relevant to its essential competence; planning the physical environment so that ideas can meet and multiply favoring creation of knowledge (ANDERSÉN, 2012); integration of reflection mechanisms in work habits; cultivation of the art of learning by doing (SANTOS et al., 2017); removal of physical and psychological barriers for sharing knowledge; creation of policies to promote ownership of knowledge (VENKITACHALAM \& AMBROSINI, 
2017); promotion of creative partnerships with other organizations; use of knowledge to strengthen the relationship with stakeholders and society (FIDEL et al., 2016); and the recognition of forms of knowledge that can be boosted and those that are limited.

When this context is delimited, KM can strengthen mechanisms for the sustainable development (SD). In other words, the authors understand that sustainable development is for ecosystem orchestration in the environmentsociety relationship in order to encourage that socioeconomic needs are met (BRUNDTLAND et al., 1987) and natural resources are preserved (ELKINGTON, 1999), favoring the economic, social, and regional environmental development. Therefore, the importance of SD for KM is in the hope that it can induce a change in behavior (FEIL $\&$ SCHREIBER, 2017) for managers to create and maintain knowledge focused on finding solutions for the short- and long-term survival and well-being of mankind (BOLIS et al., 2014).

In this process, the universities whose objective is to build and disseminate knowledge, assume the predominant role of: i) preparing people, non-governmental organizations, and other social actors so that they act as partners of the state, developing and implementing public policies to favor the sustainable development (PEER; STOEGLEHNER, 2013) and ii) sensitize political actors regarding decision making that can generate jobs, regenerate and preserve the capital of natural resources to support the subsistence means in the economy (DINDA, 2014).

Therefore, taking into account the relevance of the university in promoting the sustainable development, managers at a public institution of higher education were asked how they perceive KM in the tactical and strategic processes. The objective of this study was to analyze the knowledge management perception in managers of a public university in the Brazilian Northeastern Semiarid Region, especially their tactical and strategic processes to produce knowledge about this Region. The analysis was conducted according to the perspective of administrators at this university with a view to the sustainable development of the region.

From an academic point of view, this study is justified as it develops an integrative KM diagnosis of the tactical and strategic processes in terms of measurement and analysis (LEE et al., 2012), thus stimulating the growth of scientific discussion and progress. From the institutional point of view, this study will contribute to support action plans to improve performance of the university studied, enabling to create public value (produce services and results and build the population trust) and social capacity (competence to deal with difficult social situations). In addition, this study is relevant to develop themes that can stimulate public institutions to manage knowledge and identify the local or regional vocations to promote appropriate policies for the semi-arid region as advocated by Brito et al. (2012).

\section{MATERIALS AND METHODS}

The present study had a qualitative approach (MERRIAM, 2002) and descriptive purpose, and the mode of investigation was based on a case study (YIN, 2011). The study institution is a formal education institution and was created as Institute of Agriculture, 1967, being then incorporated into the Federal Higher Education Network. It has 40 undergraduate courses and 17 postgraduate courses, with emphasis on the areas of Agrarian, Engineering, and Multidisciplinary Sciences.

The study universe consisted of 40 administrators in the education area. They worked in four campuses of the study university, which was in the Caatinga Biome, in a state of the Northeast region of Brazil. A survey was performed within the institution's staff to select managers whose knowledge was the main resource to generate and search opportunities in the semi-arid region of Brazil.

The Knowledge Management Diagnosis (KMD), which was validated by Bukowitz and Williams (2000), was applied through a structured interview (MERRIAM, 1998) available in an electronic platform in the period of Jan-Mar 2018. The questionnaire contained 140 closed questions distributed into seven sections and two processes, as follows: i) Tactical Processes (sections obtain, use, learn, and contribute), which correspond to the staff planning/supply, application, training, and development processes, respectively; and ii) Strategic Processes (sections evaluate, build/maintain, and Dispose), which correspond to the staff performance evaluation, maintenance, and monitoring processes, respectively. Each section had a list of 20 statements, and each of them had a scale of graded (1-3 points) responses with increasing intensity: Weak (W), Moderate (M), or Strong (S).

Data interpretation was based on a grading criterion; i.e., the higher the percentage obtained in the answers, the better the performance in a specific step of the KM process. In addition, as established 
by Bukowitz and Williams (2000), for calculations in each section and for the average in the seven sections, data were organized as follows: i) total " $\mathrm{S}$ " is added to the scores " $\mathrm{S} "=3$, "M"=2, and "W"=1, and the sum is multiply by three; ii) total " $M$ " is multiplied by two, and total "W" is multiplied by one. The maximum score in each section is 60 points (20 statements $\mathrm{x} 3$ ); whereas, the overall maximum score (in all sections) is 420 points (60 points $\mathrm{x} 7$ sections). The mean scores $30-70 \%$ for each section and $55 \%$ for all sections was adopted as acceptable KM standards because these values are reported in studies validated in the USA (BUKOWITZ; WILLIAMS, 2000). Finally, to deepen the analysis of results in each KMD section, the Knowledge Management Indicators (KMI) proposed by Brito et al. (2012) were used as shown in table 1 .

To evaluate these indicators, the data collected from each issue of the study instrument were counted and the average was calculated. For analysis, Hodge e Gillespie (2007) recommends the following: i) from mean to 1.8 (poorly descriptive); ii) between 1.8 and 2.4 (moderately descriptive); and iii) greater than 2.4 (strongly descriptive). According to Merriam (1998), the internal validity and reliability of the research were assessed by means of the peer researchers in the area. The external validity is in the full description, deep understanding, and people's perception, avoiding generalizing findings for the population.

\section{RESULTS AND DISCUSSION}

It was possible to see that there is a parallelism between results reported in this study and the values reported by Bukowitz and Williams (2000) in field studies, indicating a satisfactory performance of KM in the study institution, as shown in table 2. The result by section was confirmed by the general average of all sections (58.94\%), since it presented a percent value greater than $55 \%$ as recommended by the authors of the KMD. Thus, we understood that the institution is facing the challenge of changing (from Taylorist-Fordist to learning institution), removing barriers to knowledge sharing and reconsidering its

Table 1 - Distribution of survey questions according to the Knowledge Management (KM) Indicators (KMI).

\begin{tabular}{|c|c|c|c|c|c|c|c|}
\hline KMI & Obtain & Use & Learn & Contribute & Evaluate & $\begin{array}{l}\text { Build/ } \\
\text { Maintain }\end{array}$ & Discard \\
\hline $\begin{array}{l}\text { Processes and policies for } \\
\text { knowledge management }\end{array}$ & & - & $1,10,12,15$ & $2,12,15,16,18$ & $\begin{array}{l}3,4,9,10 \\
13,14,15 \\
17,18,20\end{array}$ & $1,7,16,18$ & $\begin{array}{c}1,2,6,7,10 \\
13,16,17,20\end{array}$ \\
\hline $\begin{array}{l}\text { Sharing, communication, } \\
\text { and relationship }\end{array}$ & $1,2,4,8,9$ & $\begin{array}{c}1,5,8,15 \\
18,19\end{array}$ & 19 & $\begin{array}{c}5,7,8,10,11,12 \\
13,14,16,17 \\
18,19,20\end{array}$ & 2,12 & $1,2,19$ & $2,4,9,19$ \\
\hline Performing the task & 15 & - & - & - & - & - & - \\
\hline Roles of KM & $\begin{array}{l}3,6,10 \\
12,13,18\end{array}$ & - & - & $1,9,16$ & 14 & 3,10 & 6 \\
\hline $\begin{array}{l}\text { Physical and institutional } \\
\text { structure }\end{array}$ & & $2,3,11,13,17$ & - & $4,8,10$ & - & - & - \\
\hline $\begin{array}{l}\text { Electronic media and } \\
\text { ICTs }^{*}\end{array}$ & $\begin{array}{l}5,7,11 \\
14,16,17\end{array}$ & - & - & 4,10 & - & $\begin{array}{c}2,5,7,11,13 \\
17\end{array}$ & - \\
\hline $\begin{array}{l}\text { Documentation, } \\
\text { measurement, and } \\
\text { protocols }\end{array}$ & 19,20 & 14 & - & - & $\begin{array}{c}3,4,5,6,7 \\
8,11,12,17 \\
20\end{array}$ & 15,20 & - \\
\hline Decision-making process & - & 4 & $2,6,8,17,18,20$ & - & 13 & - & $1,3,8,13,14,15$ \\
\hline $\begin{array}{l}\text { Simulation, innovation, } \\
\text { and problem solving }\end{array}$ & - & $6,8,9,12,20$ & $4,11,13,16,20$ & - & - & $4,10,14$ & 18 \\
\hline Partnership & - & $7,10,16$ & 3,9 & 6 & - & $8,12,18$ & $11,12,19$ \\
\hline Assessment of knowledge & - & - & $5,7,9,14$ & - & - & - & $5,13,16$ \\
\hline Values & - & - & - & - & - & 6,9 & - \\
\hline $\begin{array}{l}\text { Recognition and } \\
\text { appreciation of } \mathrm{KM}\end{array}$ & - & - & - & $3,17,18$ & $1,16,19$ & - & 10,20 \\
\hline
\end{tabular}

*ICTs: Information and Communication Technologies. Source: Adapted from Brito et al. (2012). 
Table 2 - Overall scores and percentages obtained by section.

\begin{tabular}{lccc}
\hline Processes & Sections & Scores & $\%$ \\
\hline \multirow{3}{*}{ Tactical } & Obtain & 37.28 & 62.13 \\
& Use & 34.95 & 58.25 \\
& Learn & 35.05 & 58.42 \\
\hline \multirow{2}{*}{ Strategic } & Contribute & 35.83 & 59.71 \\
& Evaluate & 31.45 & 52.42 \\
& Discard & 37.05 & 61.75 \\
& & 36.35 & 60.58 \\
& & Total $=247.96$ & Mean $=58.94 \%$
\end{tabular}

Source: Research data (2017).

management practices (ALEGRE; SENGUPTA; LAPIEDRA, 2013).

In the perception of the study managers, the institution obtains uses, learns, and contributes to the knowledge (tactical processes) creating value and solving ordinary (short-term) problems. Results also revealed the existence of a certain parallelism between institutional strategies and KM practices, enabling innovation and trust to society regarding actions developed in the University in the context of the northeastern semi-arid region, that is, developing a public value.

According to the KMI respondents, it was also possible to perceive, how the institution manages the knowledge to favor the semi-arid region of Northeastern Brazil, as shown in table 3 and 4. Deepening of the KMD by means of the KMI (which moderately and weakly described how the study university manages knowledge) also identified the challenges that it still has to consolidate $\mathrm{KM}$ as a reference model to promote the development of the semi-arid region, i.e.: i) designation of specific persons or groups to articulate the information needs with databases, thus narrowing the information options to the best of the best (Obtain); ii) the use of ludic (unstructured) approaches to encourage creative thinking and solving day-to-day problems (Use); iii) transposition of the institutional limits through collaboration with organized civil society as a precondition to produce mutual gains of skills (Learn), and; iv) planning the physical environment to favor knowledge creation and dissemination (Contribute) as recommended by ANDERSEN (2012).

Some challenges still remain for the institution at the strategic level: i) description of flows in the knowledge management processes to help managers better understand what they are trying to manage; ii) knowledge evaluation through qualitative and quantitative measures to dimension its effectiveness and disseminate how knowledge is managed by the institution (Evaluate); iii) instituting knowledge sharing through technologies between institutional units and beyond frontiers of the institution and groups of work; iv) encourage managers to build innovative ideas to solve regional problems

Table 3 - Mean Knowledge Management Indicators (KMI) per Knowledge Management Diagnosis (KMD) section.

\begin{tabular}{|c|c|c|c|c|c|c|c|}
\hline \multirow[t]{2}{*}{ KMI } & \multicolumn{7}{|c|}{ - } \\
\hline & Obtain & Use & Learn & Contribute & Evaluate & Build/Maintain & Discard \\
\hline Processes and policies of knowledge management & - & - & 2.55 & - & 1.78 & 2.40 & 2.57 \\
\hline Sharing, communication, and relationship & 3.11 & 2.28 & 3.26 & 2.28 & 1.05 & 2.58 & 3.09 \\
\hline Performing the task & 3.00 & - & - & - & - & - & - \\
\hline Roles of KM & 2.16 & - & - & - & 2.55 & 2.61 & 2.21 \\
\hline Physical and institutional structure & - & 2.30 & - & 2.30 & - & - & - \\
\hline Electronic media and ICTs ${ }^{*}$ & 2.65 & - & - & - & - & 3.27 & - \\
\hline Documentation, measurement, and protocols & 2.40 & 2.50 & - & 2.50 & 1.44 & 3.03 & - \\
\hline Decision-making process & & 2.33 & 2.70 & 2.33 & 1.80 & & 2.63 \\
\hline Simulation, innovation, and problem solving & & 2.04 & 2.79 & 2.04 & & 2.40 & 3.26 \\
\hline Partnership & & 2.40 & 2.29 & 2.40 & & 2.56 & 2.40 \\
\hline Assessment of knowledge & - & - & 2.75 & - & - & - & 2.54 \\
\hline Values & - & - & - & - & - & 2.89 & - \\
\hline Recognition and appreciation of KM & - & - & - & - & 2.83 & - & 2.40 \\
\hline
\end{tabular}

*ICTs: Information and Communication Technologies. Source: Prepared by the authors (2018). 
Table 4 - Knowledge Management Indicators (KMI) containing the Knowledge Management Diagnosis (KMD) sections and study findings.

\begin{tabular}{|c|c|}
\hline KMI & 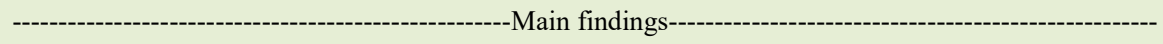 \\
\hline $\begin{array}{l}\text { Knowledge management } \\
\text { processes and policies }\end{array}$ & $\begin{array}{l}\text { Internal mistakes, failures, and disagreements are seen as opportunities to learn by the institution. In } \\
\text { addition, it seeks higher value activities or allocating people with the right skills before thinking about } \\
\text { depriving them from their positions or functions. These are characteristics of a learning institution } \\
\text { (SANTOS et al., 2017). }\end{array}$ \\
\hline $\begin{array}{l}\text { Sharing, communication, and } \\
\text { relationship }\end{array}$ & $\begin{array}{l}\text { The study institution is able to understand and communicate the intended use of information, making } \\
\text { routine its environment for knowledge, sharing among employees. This also favors cooperation and } \\
\text { complementarity of actions in the search for relevant information to favor the region where they work } \\
\text { (VENKITACHALAM \& AMBROSINI, 2017). }\end{array}$ \\
\hline Carrying out the task & $\begin{array}{l}\text { The institution employees are able to locate the information they need to improve the quality and } \\
\text { efficacy of their work to solve the regional problems (BUKOWITZ; WILLIAMS, 2000). }\end{array}$ \\
\hline KM roles & $\begin{array}{l}\text { The study institution is able to allocate or designate people and groups to assess the multidisciplinary } \\
\text { knowledge in different graduate courses provided to solve the problems of the semi-arid region when } \\
\text { resources for the innovation process are allocated (BRITO et al., 2012). }\end{array}$ \\
\hline Electronic media and ICTs* & $\begin{array}{l}\text { The institution has electronic navigation instruments (ALEGRE; SENGUPTA; LAPIEDRA, 2013) that } \\
\text { can find and capture the necessary knowledge to direct employees to the best management practices. }\end{array}$ \\
\hline $\begin{array}{l}\text { Documentation, measurement, } \\
\text { and protocols }\end{array}$ & $\begin{array}{l}\text { The study institution has high protocol levels for institutional information security, which can favor the } \\
\text { semi-arid region. Such levels can be explained by the institutional commitment for the sustainable } \\
\text { development of the region. }\end{array}$ \\
\hline Decision-making process & $\begin{array}{l}\text { The institution uses mental models to better understand why facts happen in a certain way, as well as to } \\
\text { learn how to solve problems arising from new situations. In addition, the employees reflect on how } \\
\text { much the institution can leverage the knowledge acquired about the region where it operates. }\end{array}$ \\
\hline $\begin{array}{l}\text { Simulation, innovation, and } \\
\text { problem solving }\end{array}$ & $\begin{array}{l}\text { The university uses game and simulation equipment to better understand how events happen in the } \\
\text { institutional context. In addition, the institution staff prefers to use the resources and skills built } \\
\text { according to the regional reality to test or make feasible innovative ideas for the semi-arid region. }\end{array}$ \\
\hline Partnership & $\begin{array}{l}\text { The institution participates in various communities that facilitate knowledge dissemination, expanding } \\
\text { the support network to the semi-arid region. This result showed that forming partnerships is not a } \\
\text { challenge for the study university, and this fact contrasts with the findings of Fidel, Cervera, and } \\
\text { Schlesinger (2016). }\end{array}$ \\
\hline Assessment of knowledge & $\begin{array}{l}\text { The institution administrators strongly reflect on their work experiences and the knowledge generated } \\
\text { on the semi-arid region. According to Fidel, Cervera, and Schlesinger (2016), the purpose of this } \\
\text { reflection process is to strengthen the relationship between the institution and the local society using } \\
\text { the KM efficiency. }\end{array}$ \\
\hline Values & $\begin{array}{l}\text { People are considered sources of value rather than costs, and there is an effort to combine the formal } \\
\text { values of the institution with the informal ones of its employees. }\end{array}$ \\
\hline $\begin{array}{l}\text { Recognition and appreciation } \\
\text { of KM }\end{array}$ & $\begin{array}{l}\text { The study university recognizes that knowledge about the region is a resource capable of generating } \\
\text { value for the institution in the environment where it operates. }\end{array}$ \\
\hline
\end{tabular}

*ICTs: Information and Communication Technologies. Source: Prepared by the authors (2018).

from the non-functional activities of employees (Build/Maintain) and; v) build partnerships with other institutions that act in the region to include new people as learners and determine the need to acquire new knowledge, or insert an expertise to update its knowledge base (Discard).

\section{CONCLUSION}

Knowledge management is contributing to make changes possible and generating organizational capacity for this university to implement solutions and fulfill its mission. However, KM is still maturing, as there are still challenges associated with people management, social participation, makingdecision process and flow, building partnerships, physical structure, and evaluation of organizational performance that should be overcome for KM to be consolidated as a model.

Conversely, our results also showed that university processes (including KM policies, ability to perform tasks, interpersonal communication and relationship, as well as people, groups, or communities instituted to assess knowledge, electronic media, documentation and information access protocols, simulation, and the formal university values) contributed to strengthen the relationship between the study institution and local society. Efficiency of 
$\mathrm{KM}$ and complementarity of actions will help the university to adjust its organizational system to the regional reality with view to make it more effective for society. The characteristics previously identified and clarified form a set of knowledge and practices underlying a learning institution that works for the sustainable development of the region.

Data collected in a sample from one institution is a limitation of this study, and thus the conclusions may not apply to other contexts. The study also has limitations in data triangulation. Thus, an additional survey of administrators is necessary to know how the invisible subjectivity in the activity of administrators can indicate the occult obstructions for them to have objective attitudes and overcome the remaining challenges to improve the quality of educational administration. Future longitudinal studies will better evaluate these suggestions to overcome the limitations of a unique method.

\section{DECLARATION OF CONFLICT OF INTERESTS}

The authors declare no conflict of interest. The founding sponsors had no role in the design of the study; in the collection, analyses, or interpretation of data; in the writing of the manuscript, and in the decision to publish the results.

\section{ACKNOWLEDGEMENTS}

The authors are grateful to Coordenação de Aperfeiçoamento de Pessoal de Nível Superior (CAPES) for financial support.

\section{AUTHORS' CONTRIBUTIONS}

All authors contributed equally for the conception and writing of the manuscript. All authors critically revised the manuscript and approved the final version.

\section{REFERENCES}

ALEGRE, J. et al. Knowledge management and innovation performance in a high-tech SMEs industry. International Small Business Journal, v.31, n.4, p.454-470, 2013. Available from: $<$ http://dx.doi.org/10.1177/0266242611417472>. Accessed: Dec. 13, 2017. doi: $10.1177 / 0266242611417472$.

ANDERSÉN, J. Protective capacity and absorptive capacity: Managing the balance between retention and creation of knowledge-based resources. The Learning Organization, v.19, n.5, p.440-452, 2012. Available from: <http://dx.doi. org/10.1108/09696471211239730>. Accessed: Nov. 08, 2017. doi: $10.1108 / 09696471211239730$.

ANDREEVA, T.; KIANTO, A. Does knowledge management really matter? Linking knowledge management practices, competitiveness and economic performance. Journal of
Knowledge Management, v.16, n.4, p.617-636, 2012. Available from: <http://dx.doi.org/10.1108/13673271211246185>. Accessed: Oct. 10, 2017. doi: 10.1108/13673271211246185.

BOLIS, I. et al. When sustainable development risks losing its meaning. Delimiting the concept with a comprehensive literature review and a conceptual model. Journal of Cleaner Production, n. 83, p. 7-20, 2014. Available from: <http://dx.doi.org/10.1016/j. jclepro.2014.06.041>. Accessed: Nov. 08, 2017. doi: 10.1016/j. jclepro.2014.06.041.

BRUNDTLAND, G. H. et al. Our common future / World Commission on Environment and Development. Oxford: Oxford University Press, 1987.

BUKOWITZ, W. R.; WILLIAMS, R. L. The knowledge management fieldbook. United States: Financial Times/Prentice Hall, 2000.

BRITO; L. M. P. et al. Knowledge management in a public institution for technical assistance and rural extension of northeastern Brazil. Revista de Administração Pública, v.46, n.5, p.13411366, 2012. Available from: <http://dx.doi.org/10.1590/S003476122012000500008>. Accessed: Aug. 23, 2017. doi: 10.1590/ S0034-76122012000500008.

DINDA, S. A theoretical basis for green growth. International Journal of Green Economics, v. 8, n. 2, p. 177-189, 2014. Available from: <http://dx.doi.org/10.1504/IJGE.2014.065851>. Accessed: Nov. 08, 2017. doi: 10.1590/10.1504/IJGE.2014.065851.

DONATE, M. J.; PABLO, J. D. S. de. The role of knowledgeoriented leadership in knowledge management practices and innovation. Journal of Business Research, v.68, n.2, p.360370, 2015. Available from: <http://dx.doi.org/10.1016/j. jbusres.2014.06.022>. Accessed: Nov. 08, 2017. doi: 10.1016/j. jbusres.2014.06.022.

FEIL, A. A.; SCHREIBER, D. Sustainability and sustainable development: unraveling overlays and scope of their meanings. Cadernos EBAPE.BR. Rio de Janeiro, RJ, v.14, n.3, p.667-681, jul./set., 2017. Available from: <http://www.scielo.br/pdf/cebape/ v15n3/en_1679-3951-cebape-15-03-00667.pdf >. Accessed: Sep. 18, 2017. doi: 10.1590/1679-395157473.

FIDEL, P. et al. Customer's role in knowledge management and in the innovation process: effects on innovation capacity and marketing results. Knowledge Management Research \& Practice, v.14, n.2, p.195-203, 2016. Available from: <http:// dx.doi.org/10.1057/kmrp.2015.19>. Accessed: Oct. 19, 2017. doi: 10.1057/kmrp.2015.19.

HODGE, D. R.; GILLESPIE, D. F. Phrase completion scales: a better measurement approach than Likert scales? Journal of Social Service Research, 33 (4), p.1-12, 2007. Available from: $<$ http://dx.doi.org/10.1300/J079v33n04_01>. Accessed: Jan. 15, 2019. doi: 10.1300/J079v33n04_01.

LEE, S. et al. An integrated view of knowledge management for performance. Journal of Knowledge Management, v.16, n.2, p.183-203, 2012. Available from: <http://dx.doi. org/10.1108/13673271211218807>. Accessed: Oct. 13, 2017. doi: $10.1108 / 13673271211218807$.

MERRIAM, S.B. Qualitative research in practice: Examples for discussion and analysis. Jossey-Bass Inc Pub, 2002. 
MERRIAM, S. B. Case study research in education: A qualitative approach. Jossey-Bass Inc Pub, 1998.

PEER, V.; STOEGLEHNER, G. Universities as change agents for sustainability-framing the role of knowledge transfer and generation in regional development processes. Journal of Cleaner Production, v.44, p.85-95, 2013. Available from: $<\mathrm{http} / / \mathrm{dx}$.doi. org/10.1016/j.jclepro.2012.12.003>. Accessed: Oct. 17, 2017. doi: 10.1016/j.jclepro.2012.12.003.

SANTOS, R. S. dos et al. LEARNING ORGANIZATIONS subjects for management with people in the public service. Holos, v. 8, p. 205-228, 2017. Available from: <http://dx.doi. org/10.15628/holos.2017.5171>. Accessed: Nov. 19, 2017. doi: 10.15628/holos.2017.5171.

ELKINGTON, J. Cannibals with forks. Canada: New Society, 1999.

VENKITACHALAM, K.; AMBROSINI, V. A triadic link between knowledge management, information technology and business strategies. Knowledge Management Research \& Practice, v.15, n.2, p.192-200, 2017. Available from: <http://dx.doi.org/10.1057/ s41275-016-0043-5>. Accessed: Oct. 22, 2017. doi: 10.1057/ s41275-016-0043-5.

YIN, R. K. Applications of case study research. California: Sage, 2011. 